\title{
In vivo floresan görüntüleme ve in vivo uygulamalarda kullanılan florofor bileşikler
}

\author{
In vivo fluorescence imaging and fluorophores used in in-vivo applications
}

\author{
Erdal Tunç
}

Gönderilme tarihi: 09.07.2019

Kabul tarihi: 30.09 .2019

\begin{abstract}
Özet
Geleneksel olarak kültür ve hücre izlemelerinde kullanılan floresan ışımaya dayalı görüntüleme teknikleri, son on-yıllarda in vivo izlemelerde de kullanıımaya başlanmıştır. Çoğunlukla küçük laboratuvar hayvanlarına uygulanan FLIM, FRET, FRI gibi in vivo görüntüleme düzenekleri hedeflenen bir proteinin veya biyo-molekülün gerçek zaman-mekanda in vivo görüntülerinin alınmasında kullanılılar. Bu düzenekler genel olarak hayvanın üzerine konacağı sahne, bir floresan uyarıcı ışık kaynağı, gelen ve emisyon ışık filtreleri, kamera aparatı (CCD kamera) ve dataları alıp analiz eden bir yazılım programı elemanlarından oluşmaktadırlar. Floresan işaretleme esasına dayalı çalışan herhangi bir in vivo izleme sisteminin dizaynı iki adımda gerçekleştirilir; öncelikle izleme için hedef seçilen protein veya biyo-molekül uygun bir florofor ile işaretlenir, daha sonra işaretli biyo-molekül canlı bünyede görüntülenir. İn vivo uygulamalarda kullanılan floresan problar; hedef gözetmeyen problar, hedefli aktif problar, hedefli aktive edilebilen problar ve nano-partiküller şeklinde sınıflandırılabilirler. İlave olarak, bir söndürücüye konjuge floresan problar, hedeflerine bağlandıktan sonra quantum verimlerini arttıran florofor problar, organellere spesifik olarak bağlanan floresan problar, iki foton absorbsiyonu esasına dayalı çalışan floresan problar, dönebilen konjuge grup içeren florofor problar ve yakın kızılötesi nanopartiküller diğer önemli floresan prob kategorilerini oluşturmaktadırlar. Genel olarak floresan boyaların hedef/arka-plan ışıma kontrastı, hedefine özgün bağlanma, quantum verimi, absorbsiyon ve emisyon dalga boyları, suda çözünürlük, hücreye nüfuz edebilme ve floresan yaşam-süresi gibi özelliklerinin geliştirilmesi; bu boya maddelerini klinik kullanım açısından elverişli hale getirecektir. Bu derlemede floresan ışımanın mekanizması, floresan ışıma prensibine dayalı olarak çalışan ve önemli görülen in vivo görüntüleme teknikleri ve florofor bileşikler hakkında bilgi verilmesi ve konuyla ilgili önemli çalışmaların gözden geçirilmesi hedeflenmiştir.
\end{abstract}

Anahtar kelimeler: Floresan ışıma, floresan prob, görüntüleme tekniği, biyomolekül.

Tunç E. In vivo floresan görüntüleme ve in vivo uygulamalarda kullanılan florofor bileşikler. Pam Tıp Derg 2020;13:235-247.

\begin{abstract}
Fluorescence imaging techniques that are conventionally used in culture and cell assays have started to be used in in-vivo assays in the last decades. In vivo fluorescent assay set-ups such as FLIM, FRET, FRI, which are mostly applied to small laboratory animals, are used for taking spatiotemporal in vivo images of any targeted protein or biomolecule. Those set-ups constitute mainly from animal placement stage, an excitation light source, excitation and emission light filters, camera (charge couple device, CCD) and data collecting/processing software components. Design of any in vivo assay system, which works based on fluorophore labeling, includes two steps; firstly, any targeted protein or biomolecule is tagged with appropriate fluorophore and then, this tagged protein is visualized in the body of living animal. In vivo fluorescent probes can be classified as nontargeting probes, active targeting probes, activable targeting probes and fluorescent nanoparticles. Besides, quencher-conjugated fluorescent probes, turn-on fluorophore probes which increase their quantum yields upon binding to their targets, organelle-specific fluorescent probes, two-photon absorption (TPA) fluorescent probes, rotatable conjugated moiety-containing fluorophore probes, near-infrared (NIR) nanoparticles are other important fluorescent probe categories. In general, fluorescent dyes require improvements in their properties of background/target ratios, specificity, quantum yields, absorption and emission wavelengths, water solubility, cell permeability and fluorescent lifetimes, for use in clinical applications. In this study, it was aimed to review important studies and provide knowledge about general mechanism of fluorescence, some important fluorescence-based in vivo imaging techniques and in-vivo applicable fluorophore compounds.
\end{abstract}

Key words: Fluorescence, fluorescent probe, imaging technique, biomolecule.

Tunç E. In vivo fluorescence imaging and fluorophores used in in-vivo applications. Pam Med J 2020;13:235247. 


\section{Giriş}

Optik görüntüleme teknikleri, gösterdikleri yüksek çözünürlük gücü ve hassasiyetlerinden dolayı uzun yıllardan beri histoloji, biyo-izleme ve mikroskobi uygulamalarında kullanılmaktadırlar [1]. Bu bağlamda ele alınan floresan teknikler, floresan bileşiklerin gerçekleştirdikleri floresan ışıma olgusunu görüntüleme teknolojisi haline dönüştüren tekniklerdir. Bir dalga boyundaki ışığa maruz kaldığında, daha uzun dalga boyunda ışık üreten maddelere floresan maddeler denir [2, 3]. Kimyasal olarak floresan bileşikler, genellikle aromatik yapıdadırlar ve konjuge pi bağları (moleküler kompozisyonda tekli bağ ile ayrılan çift bağlar) içerirler. Ancak son zamanlarda aromatik olmayan bazı biyomakromoleküllerin ve polimerlerin de (protein fibriller, polipeptidler, poli-amido aminler, poli-etilenimin, çok dallı yapı gösteren poli-amino ester ve poli-ürea dendrimerler) aggregat halde ve solüsyon içerisinde floresan özellik gösterebildikleri rapor edilmiştir [4, 5]. Herhangi bir florofor (bir kimyasal bileşiğe bağlandığında ona floresan özellik kazandıran floresan boya maddesi, reaktif boya), bir ışık kaynağından gelen ışığa maruz kaldığında uyarılır ve bu uyarılma sürecinde, florofor molekülün zayıf bağlı elektronlarından biri yüksek enerji düzeylerine çıkar. S1 veya $\mathrm{S} 2$ düzeyleri olarak tanımlanan singlet durumlarda (singlet states) elektronun kendi ekseni çevresindeki dönüş yönü (spin) değişmez. Daha sonra elektron temel haline (ground state) geri dönerken (SO) dışarıya enerji verir. Dışarıya enerji verme iki şekilde olur. Floresan molekül ışıma yapmadan ısı enerjisi yayabilir veya ışıma yaparak floresan foton yayabilir. Floresan foton yayma durumunda floresan ışıma gerçekleşmiş olur. Floresan yaşam süresi (birçok floresan protein ve floresan boya için 1 il 5 ns arasındaki bir süre), bir florofor molekülün uyarılmaya bağlı olarak elektronik uyarılma düzeyi olan S1'de ne kadar süreyle kaldığını ifade eder. Kimi durumlarda uyarılmaya bağı olarak elektron, singlet durumdan triplet duruma (triplet state) geçer. Triplet duruma geçen elektronun dönüş yönü değişir. Elektronun triplet durumdan temel duruma dönerken yaptığı ışımaya fosforesan (phosphorescence) ışıma denir. (Şekil 1,2 ve 3'üncü kaynaklardan uyarlanmıştır) [2, 3, 6, 7].

Bütün bu fiziko-kimyasal süreçlerin sonucu olarak floresan bileşik, kendisini uyaran ışığa (gelen ışığa) nisbeten daha büyük dalga boylu/ daha düşük enerjili ışıma yapar veya soğurduğu ışıktan farkı renkte ışık verir. Floresan bileşiklerin absorbe ettikleri ışık ile çıkardıkları ışığın dalga boyları arasındaki farka stokes değişimi denir. Elektronların oluşturduğu enerji değişiminin tabiatı gereği stabil ve parlak ışıma veren florofor bileşiklerin absorbe ettikleri ve çıkardıkları ışıkların dalga boyları 300 ile 700 $\mathrm{nm}$ arasında değişmektedir $[3,5,7,8]$. Ancak bu aralığın dışındaki dalga boylarında absorbsiyon ve emisyon yapan florofor bileşikler de mevcuttur [9-12]. Ultraviyole dalga boylarındaki gelen ışıklar, moleküllerde iyonizasyona yol açtıklarından dolayı floresan uyarıcı ışık olarak kullanılamazlar $[3,5,7,8]$.

Floresan ışımaya dayalı floresan mikroskobi tekniği 1911 yılından beri bilimsel araştırmalarda kullanılmaktadır. Ancak son zamanlarda oluşturulan kompleks düzenekler yardımıyla floresan görüntüleme teknikleri in vivo izleme çalışmalarında kullanıımaya başlanmıştır. İn vivo floresan görüntüleme teknikleri olarak FLIM (fluorescence lifetime imaging, floresan yaşamsüreli görüntüleme), FRET (Förster resonance energy transfer, Förster veya floresan rezonans enerji transferi) ve FRI (fluorescence reflectance imaging, whole body fluorescence reflectance imaging, floresan-reflektans görüntüleme) teknikleri özellikle canlı deneysel çalışmalarda kullanılmaktadırlar. İlk olarak 1946 yılında teorik çerçevesi ortaya konan FRET tekniği in vivo protein etkileşim çalışmalarında kullanılmaya başlanmıştır. Yine FLIM ve FRI teknikleri son yıllarda in vivo izlemelerde kullanılmaya başlanan ve in vivo görüntüleme açısından gelecek vadeden önemli tekniklerdir [1, 2, 13, 14). Sözü edilen in vivo izleme düzeneklerinin etkin kullanımları, uygun floresan boyaların veya florofor bileşiklerin seçilmesini veya kimi durumlarda uygun konjugatların kimyasal olarak sentezini gerekli kılmaktadır. Bu bağlamda kullanılacak olan ideal bir floresan materyalin in vivo ortamda kararlı olması, hedeflenen bölgede toplanabilmesi ve kontrast oluşturarak hedefi görünür hale getirebilmesi gerekmektedir. Yine floresan materyalin yüksek floresan etkinliğe sahip olması, suda iyi çözünebilmesi ve biyolojik bünyeye uyumlu olması göz önünde bulundurulması gereken diğer özelliklerdir $[14,15]$. Bu derlemede floresan ışımanın mekanizması, floresan ışımaya dayalı in vivo görüntüleme sistemleri ve yukarıda ifade edilen 


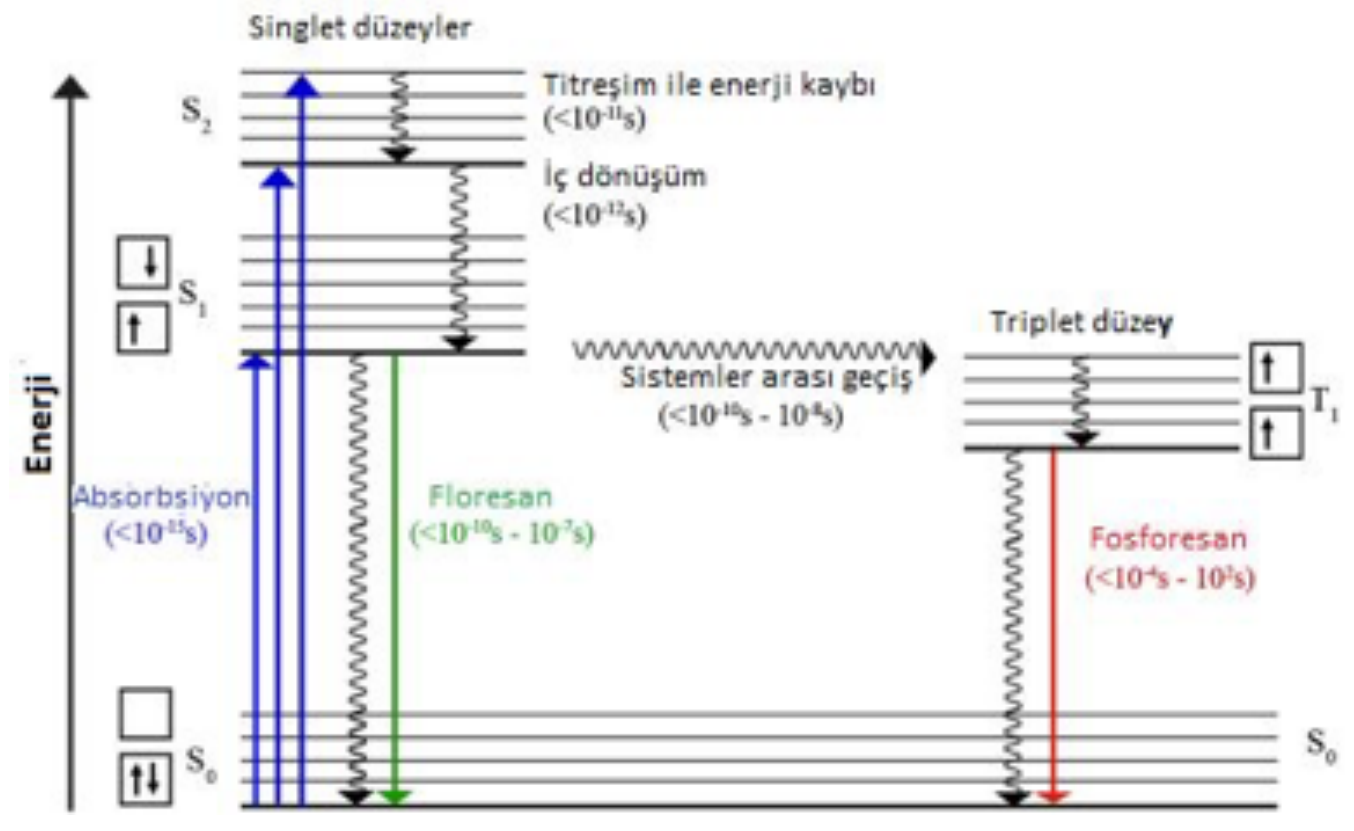

Şekil 1. Floresan ve fosforesan ışımalara yol açan foto-fiziksel süreçleri gösteren Perrin-Jablonski diagramı. Diagramda bir sistemdeki elektronların bulunabilecekleri $S=0, S=1$ veya $S=2$ olarak ifade edilen farklı enerji seviyeleri verilmiştir. Elektronların spin quantum sayıları $(-1 / 2,+1 / 2)$ ile karakterize açısal hızları vardır. Bir elektronun singlet düzeyi olarak tanımlanan düzende; $S=0$ temel seviyeyi, $S=1$ ilk uyarılma seviyesini göstermektedir. Uygun enerjili bir foton bir moleküle çarptığında, ilgili molekül enerji soğurur (fotonun enerjisini alır) ve bir elektronu quantum dönme sayısını koruyarak, yüksek enerji seviyesine çıkar. İç dönüşüm kavramı, ışıma olmadan en düşük uyarılma düzeyine (en düşük titreşim düzeyine) geçişi ifade eder. Bir süre sonra ilgili elektron temel enerji düzeyine iner ve bu esnada floresan ışıma meydana gelir. Kutu içerisindeki oklar farklı düzeylerdeki elektronların dönüş yönlerini göstermektedirler. Okların yönleri göz önüne alındığında elektronların dönüş yönlerinin (spinlerinin) singlet halde değişmediği, ancak triplet halde değiştiği görülmektedir.

ideal bir floresan maddede bulunması gereken özellikleri belli oranlarda taşıyan farklı florofor bileşikler ve bu bileşiklerin çalışma prensipleri hakkında bilgi verilmesi hedeflenmiştir. Dünya ölçeğinde üzerinde çalışmaların sürdüğü in vivo floresan görüntüleme teknolojisi ile ilgili olarak oldukça sınırlı miktarda Türkçe literatür bulunmaktadır. Bundan dolayı bu derleme, gelecekte bu konuyla ilgili çalışma yapacak olan araştırmacılara konuya giriş düzeyinde Türkçe kaynak oluşturacaktır.

\section{İn vivo floresan görüntüleme teknikleri}

Çok farklı düzenekler geliştirilmiş olmasına rağmen floresan görüntüleme teknikleri temel olarak, floresan mikroskobiye dayalı incelemeler ve floresan ışımaya dayalı makroskobikinceleme düzenekleri olarak kategorize edilebilirler. İn vivo floresan görüntüleme teknikleri, kamera ve uygun filtre sistemlerinden oluşan makroskopik izleme teknikleridir. Bu tekniklerle incelenen objeler fare, sıçan gibi küçük laboratuvar hayvanlarıdır [15]. Bu derlemede, in vivo floresan görüntüleme teknikleri olarak FLIM, FRET ve planar yakın kızılötesi floresan görüntüleme (planar NIR fluorescence imaging, FRI) teknikleri ele alınmıştır $[1,13]$.

\section{FLIM (Fluorescence lifetime imaging, Floresan yaşam-süreli görüntüleme) tekniği}

Bir florofor bileşiğin floresan yaşam-süresi, ilgili floroforun ortalama olarak ne kadar süreyle uyarılmış halde kalabildiğini ifade etmektedir. Herhangi bir floroforun yaşam-süresi IsI, pH, viskozite, iyon konsantrasyonu, oksijen doyumu, protein veya moleküllerle yaptığı bağlar gibi moleküler-çevresel etmenlere bağlıdır. Bu derleme kapsamında incelenen birinci in vivo floresan görüntüleme tekniği olarak FLIM, canlı doku ortamına verilmiş olan florofor bileşiklerin karakteristik emisyon yaşam-süreleri arasındaki farklardan yararlanma ve bu prensibe dayalı 
olarak oluşan ışımaların görüntüye çevrilmesi esasına bağı olarak çalışır. Başka bir ifade ile, özellikle uyarım ve emisyon spektrumları çakışan florofor bileşiklerin uyarılmış halde kalma süreleri (floresan yaşam-süreleri) üzerinden ayrılmaları ve bu farklılığın görüntüleme teknolojisine dönüştürülmesi FLIM tekniğinin esasını oluşturmaktadır [16-18]. Floresan yaşam-süresi, bir florofor bileşiğin yapısal özelliği olmakla birlikte, ilgili floroforun içinde bulunduğu mikro-çevreden de etkilenir. Dolayısıyla FLIM tekniği, izlenen floroforun çevre şartları hakkında da bilgi verir [19]. Bu özelliğin sonucu olarak bazı durumlarda FLIM tekniği, aynı floroforun çevreleriyle değişik etkileşimler içerisinde olan farklı kısımlarının ayırt edilmesinde de kullanılır [20]. Bu prensibe göre çalışan bir FLIM düzeneği; optik anahtar, ayarlanabilir vuruşlu lazer kaynağı, zaman bağdaşımlı foton sayacı (time-correlated single photon counter, TCSPC), foto-çoğaltıcı tüp (Photomultiplier tube, PMT), ısı kontrollü tarama sahnesi, ışığı aktaran fiberler, soğutmalı CCD kamera, uygun floresan filtreler, görüntüleri alan ve analiz eden bir yazılım programından oluşmaktadır. Floresan yaşam-süreli görüntülemede, görüntüyü oluşturan datalar, zaman (time domain) veya frekans ölçümleri (frequency domain) esas alınarak alınır ve işlenir [13]. Zaman ölçümlü FLIM düzeneğinde veriler TCSPC sayacı üzerinden okunur. Bu düzenekte incelenecek örnek, yüksek frekansta vuruş yapan lazer ışıkla taranır. Lazer vuruş anı ile oluşan floresan fotonun varış anı arasındaki zaman belirlenir ve bu şekilde tek tek bütün floresan fotonlar için elde edilen datalar kaydedilir. Ayrıca fotonun elde edildiği anda lazer ışığının odaklandığı pozisyonda değerlendirilir. $\mathrm{Bu}$ parametrelerin işlenmesiyle fotonların dağılımları ve oluş zamanları (lazer vuruşlarına nispetle) koordinat sistemi üzerinde gösterilir. Sonuçta iki boyutlu taramalardan üç boyutlu data dizileri elde edilmiş olur [20]. Frekans ölçümlü FLIM düzeneğinde ise ölçüm ışığın dalga modeli (analog dalga formu) üzerinden gerçekleştirilir. İncelenecek materyal modüle edilmiş veya vuruşlu ışık ile uyarıır. Neticede gelen uyarıcı ışıkla kıyaslandığında, örnek materyalin yaydığı floresan ışığın modülasyon derecesi düşer ve ışık faz değişimine uğrar. Bu değişim değerlerinin ölçümüne dayalı datalar elde edilir. Başka bir ifade ile gelen uyarıcı ışığa kıyasla örnek materyalin yaydığı floresan ışığın modülasyon derecesinde meydana gelen düşme ve faz değişimi değerlerinden floresan yaşamsüresi belirlenir [20]. FLIM tekniği, hücrelerin fonksiyonlarının değerlendirilmesinde, proteinprotein etkileşim çalışmalarında, protein izleme çalışmalarında ve DNA yapı çalışmalarında kullanılan bir tekniktir. FLIM tekniğine dayalı in vivo çalışmalar ile özellikle hastalıkların gelişim seyirlerine bağlı olarak gelişen ve hücre fonksiyonlarını etkileyen moleküler değişimlerin izlemesi yapılabilmektedir. Özellikle yakın kızıl ötesi floresan probların kullanıldığı FLIM çalışmalarıyla derin dokuların ve tümörlerin gelişim seyirlerinin izlenmesi olanaklı hale gelmektedir [13]. Illave olarak ilaçların vücuttaki dağılımları ve metabolizmaları ile ilgili çalışmalarda, doku canlıığını izleme ve pigmentasyon ile ilişkili deri hastalıkları çalışmalarında FLIM tekniğinden faydalanılmaktadır (Şekil 2, 13'üncü kaynaktan uyarlanmıştır) [16].

\section{FRET (Förster resonance energy transfer, Förster veya floresan rezonans enerji transferi) tekniği}

Bu derlemede ele alınan ikinci teknik olarak FRET tekniği, iki floresan bileşik arasında dipol-dipol eşleşmesi mekanizması ile ışımasız enerji transferi prensibine dayalı çalışan bir tekniktir. Özgün dalga boylu ışınla uyarılan birinci florofor bileşik (donör), rezonans enerji transferi yoluyla ikinci florofor bileşiği (alıcı) uyarır. Bu şekilde uyarıımış olan alıcı florofor bileşik emisyon yaparak, ortama foton yayar. Rezonans enerji transferinin gerçekleşmesi için donör ve alıcı florofor bileşiklerin çok yakın pozisyonda olmaları (1-10 nm mesafede) ve uygun yönlerde dizilmiş bulunmaları gerekir. Yine FRET'in oluşması için donör emisyonu ile alıcının uyarılma enerjileri arasında spektral uyum olması da gerekir. Bu teknik özellikle protein-protein etkileşim çalışmalarında kullanılmaktadır. Çalışılacak proteinlere, doğal floresan proteinlerle kaynaştırma veya uygun florofor bileşiklere bağlama yöntemlerinden birisi kullanılarak floresan özellik kazandırılır. Bu şekilde floresan olarak işaretlenmiş iki protein arasındaki etkileşim durumu izlenir [6, 21, 22]. Işıma yoğunluğu (steady-state, intensity based) veya floresan yaşam-süresi (FLIM-FRET) prensiplerine göre çalışan FRET görüntüleme düzenekleri bulunmaktadır $[21,23]$. Işıma yoğunluğuna dayalı FRET ölçümlerinde donör ve alıcı moleküllerin floresan ışıma yoğunlukları 


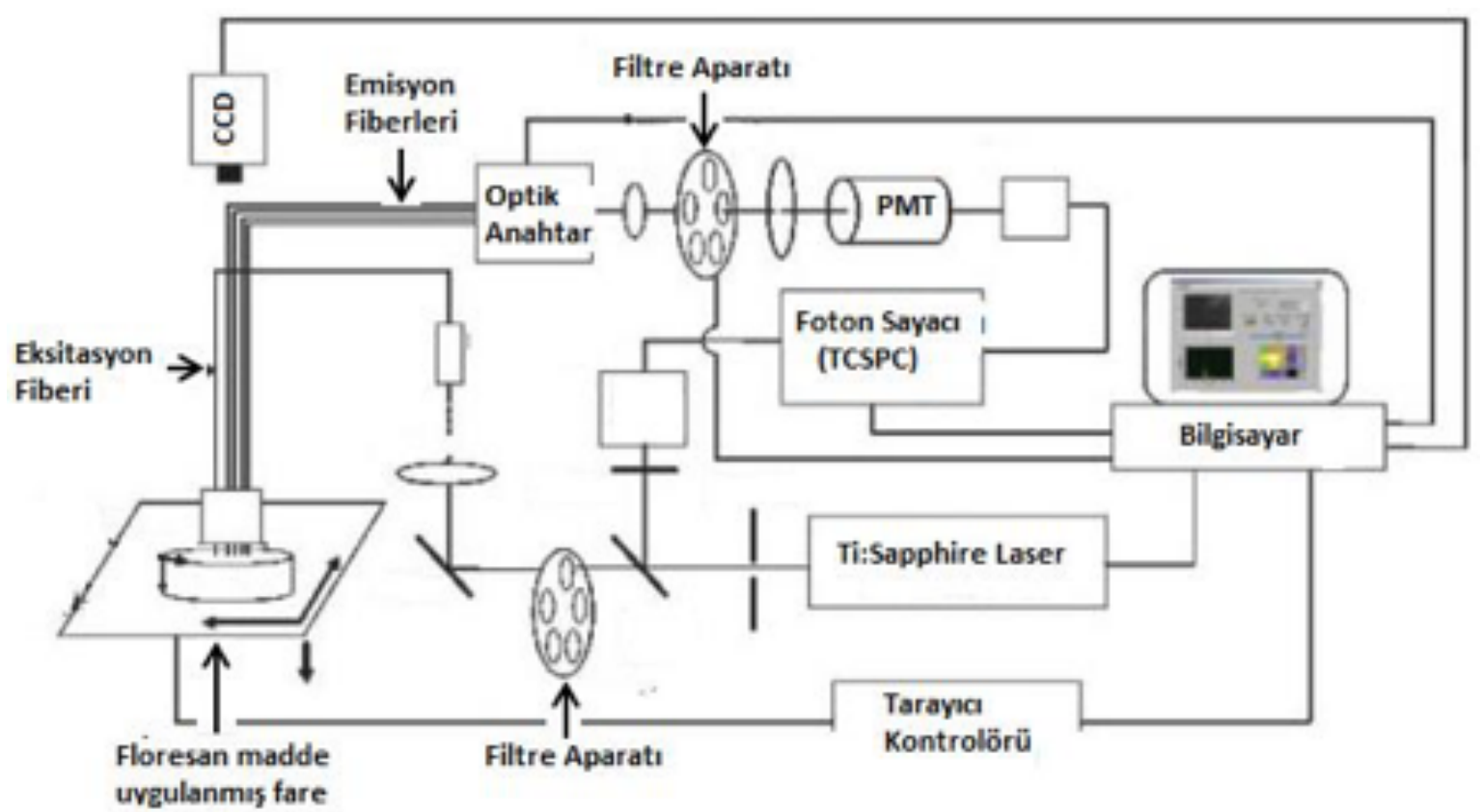

Şekil 2. A) FLIM (Fluorescence lifetime imaging, Floresan yaşam-süreli görüntüleme) tekniği ile in vivo fare izleme düzeneğinin şematize gösterimi.

konsantrasyona bağlıdır. FLIM-FRET tekniğinde ise donör bileşiğin floresan yaşam-süresinin ölçülmesi esastır [20]. Çalışılan proteinlerin floresan proteinlerle füzyon yapması esasına göre oluşturulmuş FRET düzenekleri olduğu gibi, floresan boyalarla işaretleme esasına göre oluşturulmuş olan FRET düzenekleri de bulunmaktadır [22-24].

FRI (Fluorescence reflectance imaging, Floresan-reflektans görüntüleme) tekniği

Üçüncü olarak planar yakın kızılötesi floresan görüntüleme tekniğinde fare veya sıçanlara verilen floresan problar, FRI sistemi ile izlenir (Şekil 3, 1'inci kaynaktan uyarlanmıştır). Bu teknik, birden fazla hayvanın bir anda izlenmesini olanaklı kılan ve kolay görüntü analizine olanak sağlayan önemli bir tekniktir. Bir planar yakın kızılötesi floresan görüntüleme düzeneği, başlıca; üzerine hayvanların konacağı destek düzeneklerini içeren görüntüleme kabini (lighttight imaging chamber), CCD (charge coupled device) kameraya dayalı preklinik FRI sistemi, geniş bantta ışık yayan (xenon) ışık kaynağı, uyaran ışık filtreleri, emisyon ışık filtreleri, soğutmalı dijital kamera ve görüntüleri toplayan ve analiz eden bir software programı parçalarından oluşmaktadır. Düzenek kabaca şöyle çalışır: Kullanılan floresan probun absorbsiyon ve emisyon dalga boylarına uygun floresan filtreler seçilir. Uyaran ışık filtresi ışık kaynağı ile denek hayvan arasına, emisyon filtresi denek hayvan ile kamera arasına yerleştirilir. Anestezik madde (\%2 izofluran veya $100 \mathrm{mg} / \mathrm{kg}$ ketamin-10 mg/kg ksilazin kokteyli maddelerinden birisi) verilerek uyuşturulmuş olan hayvan, görüntüleme kabini içerisindeki platformun üzerine yerleştirilir. Denek hayvanın platforma, esas görüntü alınacak vücut bölgesinin (region of interest, ROI) kameranın görüş açısı içerisinde olacak şekilde yerleştirilmesi, istenen görüntünün elde edilmesi açısından önemlidir. Kamera ve ilgili yazııım programı yardımıyla görüntüler toplanır ve analiz edilir. Son olarak hayvan, soğutma yastığı (warming pad) üzerine alınır ve uyanması beklenir [1]. Yukarıda ana-hatlarıyla ifade edilen görüntüleme düzeneklerinin istenen verimde çalışması, takibi yapılacak olan protein veya moleküllerin uygun floresan işaretleyicilerle işaretlenmiş olmasına bağlıdır. 

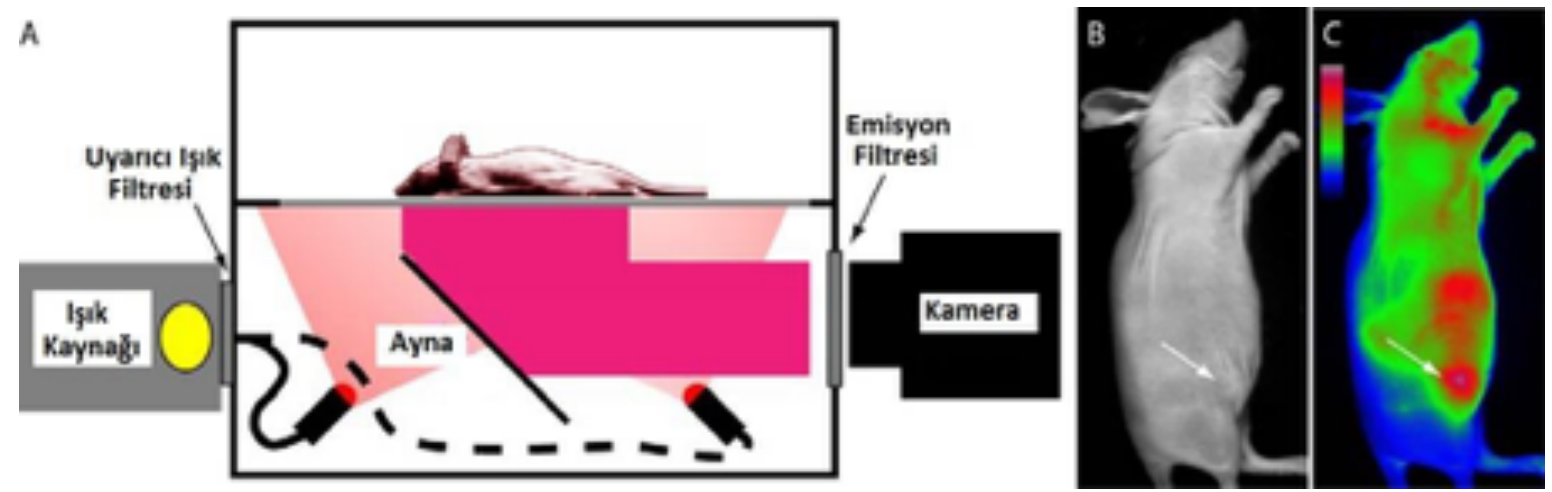

Şekil 3. A) Planar FRI sisteminin basit şematize görünümü. B) Subkutanöz tümörü bulunan farenin aydınlık saha görüntüsü. C) Aynı farenin yakın kızılötesi floresan probla (630 nm' de uyarılan ve 700 nm'de emisyon yapan IntegriSense 680 probu) işaretli görüntüsü.

\section{Önemli floresan problar}

Floresan görüntüleme düzeneği oluşturmak üzere kullanılan problar, hedef gözetmeyen problar ve hedefli problar olarak kategorize edilebilirler. Hedef gözetmeyen problar, sistemik izlemelerde kullanılmaktadırlar. Bu tip problar, deney hayvanlarında (sıçan, fare, domuz) kan akımı, klirens, damar izleme ve lenf nodlarının takibi çalışmalarında kullanılmaktadırlar. Hedefli problar, (florokrom, florofor veya kromofor bileşikler) hedef bölgedeki hücrelerin reseptörlerine bağlanan ligandlara konjugat olarakbağlanırlar[15, 25]. Hedefli problaraörnek olarak kanserli hücrelerin takibinde kullanılan ve kanser hücrelerine bağlanan ligandlara konjuge olan problardan söz edilebilir. Bu tip izleme düzeneklerinde hedefli probların konjuge oldukları ligandlar, kanserli hücrelere özgü yüzey reseptörlerine bağlanırlar. Sözü edilen ligandlar küçük moleküller, peptidler, proteinler veya antikorlar olabilirler. Bu kategori hedefli problar, aktif problar (active probes) olup, özgün dalga boylu ışıkla uyarıldıklarında hemen floresan ışıma yaparlar. Bunlara ilave olarak aktive edilebilen hedefli problar (activable probes) denilen bir grup prob, enzim çalışmalarında kullanılmaktadırlar. $\mathrm{Bu}$ probların çalışma sisteminde; iki veya daha fazla kromofor bileşik, aktivitesi test edilecek enzimin özgün olarak kesebildiği bir peptid bağlayıcı aracılığıyla belli bir yakınlık derecesinde bağlanırlar. Bu öyle bir yakınlık mesafesidir ki, bu şekilde bağlı oldukları halde birbirlerinin floresan emisyonlarını söndürürler ve nihayetinde problar bağlı halde floresan ışıma meydana getiremezler. Ancak, tutundukları peptid bağlayıcıların kırılması ve serbestleşmeleri durumunda floresan bileşikler normal floresan işlevlerini görmeye başlarlar. Bu durumda florofor bileşiklerin serbestleşmeleri ve normal floresan işlevlerini görmeye başlamaları, ilgili enzimin peptid bağlayıcıyı kestiği anlamına gelir (Şekil 4, 15'inci kaynaktan uyarlanmıştır) [15].

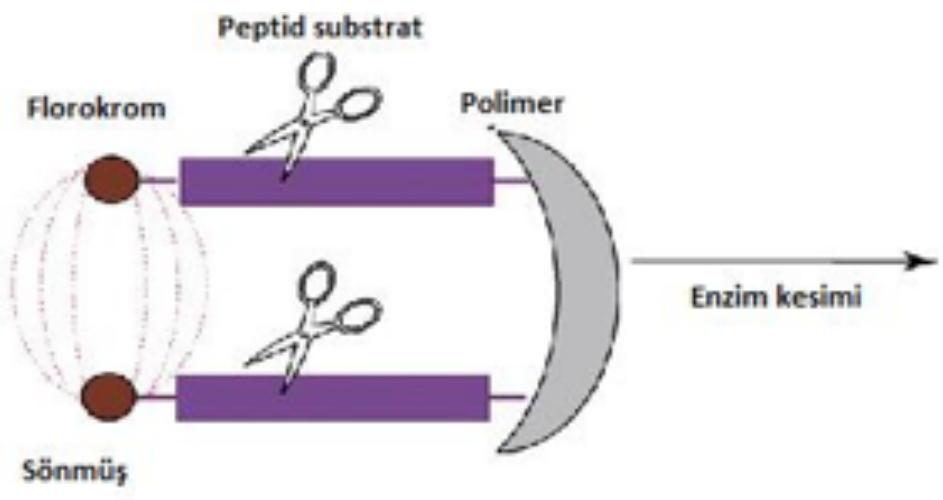

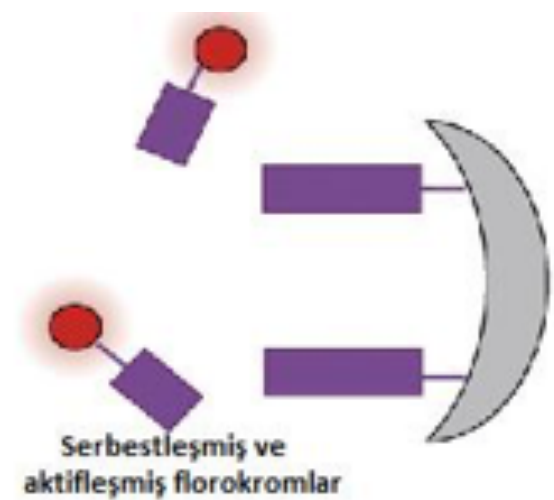

Şekil 4. Enzimatik kesim ile aktifleşen yakın kızılötesi florojenik probların çalışma mekanizmalarının şematize görünümü. 
Herhangi bir florofor bileşik hedef molekülüne (örneğin aminoasite veya proteine) doğrudan bağlanabilir veya floresan özelliği olmayan başka bir bileşikle konjugat oluşturmuş halde hedef molekülüne yönlendirilebilir. Konjuge florofor bileşik düzeneğinde, floresan özelliği olmayan bileşik hedef moleküle bağlanmadan önceki süreçte söndürücü (quencher) görevini üstlenir ve florofor bileşiğin ışıma yapmasını engeller. Ancak hedef molekül ile etkileşme olduğunda, konjuge çifti oluşturan söndürücü bileşik ile floresan ışıma yapacak olan bileşik arasındaki kimyasal bağ kırılır ve serbestleşen florofor bileşiğin gerçekleştirdiği floresan ışıma görünür hale gelir. Bu durumda floresan ışımanın gözlenmesi, konjuge florofor bileşiklerin hedef molekülleri ile etkileştikleri anlamına gelir. Örneğin biyotiyol (biothiol) bileşikler (sistein, homosistein, glutatyon) ile etkileşen kumarin-malonitril (coumarinmalonitrile) konjuge floresan bileşikleri bu şekilde çalışmaktadırlar. Bu düzenekte kumarin florofor, malonitril söndürücü olarak görev yapar [26]. Geliştirilmiş olan bazı florofor problar ise hedef moleküllerine bağlanmadıkları sürece ışıma yapmazlar veya düşük düzeyde ışıma yaparlar. Ancak hedeflerine bağlandıktan sonra ışımalarını yoğunlaştırırlar (quantum verimlerini arttırırlar). Bu tip probların ayrıca söndürücü moleküllerle konjuge edilmeye intiyaçları yoktur. Örneğin Alzheimer hastalığına bağlı olarak beyinde oluşan amiloid- $\beta$ plaklarına bağlanan DANIR floroforlar bu kategoride değerlendirilen problardır [26, 27]. Yine albümin proteinine bağlandıktan sonra floresan ışımasını anlamlı düzeyde arttıran uzak kızıl-ötesi spektrumdaki indosiyanin türevi ile kan beyin bariyerini aşarak $\beta$-amiloid peptide bağlandıktan sonra aktifleşen yakın kızıl-ötesi spektrumdaki NIAD-4 florofor bileşikleri bu kategoride değerlendirilebilirler [15]. Ayrıca hücre zarına, lizozomlara ve mitokondrilere spesifik olarak bağlanabilen lipofilik floresan problar geliştirilmiştir. Bu problar sayesinde sözü edilen organeller in vivo olarak izlenebilmektedirler. Bu tip probalara örnek olarak son zamanlarda geliştirilmiş olan ve lizozoma bağlanabilen CTNF126 (cell-tracking NIR fluorophore 126, hücre izleyen yakın kızılötesi florofor 126) probundan söz edilebilir. Yine CTNF103 floresan probu bu kategoride değerlendirilebilir [28]. Benzer şekilde mitokondri organeline bağlanan ve mitokodrinin canlı olarak izlenmesini olanaklı kılan florofor bileşikler de mevcuttur. Mitokondriye seçici bir şekilde bağlanan ve splendor adı verilen florofor bileşik BTD (2,1,3-benzothiadiazole) türevi olarak sentezlenmiştir. Spesifik olarak mitokondrinin iç ve dış zarında bulunan adenin nükleotid translokaz (ANT) molekülüne bağlandığı düşünülmektedir. $\mathrm{Bu}$ şekilde mitokondriye bağlanan splendor, yeşil floresan ışıma vererek mitokodrinin canlı olarak izlenmesini olanaklı kılmaktadır [29]. Bazı floresen problar canlı hücrede ancak yüksek hidrojen iyon konsantrasyonu ortamında, örneğin lizozomlarda, proton bağladıktan sonra ışıma yapmaya başlarlar. $\mathrm{H}-\mathrm{ICG}(\mathrm{H}$-indocyanine green, $\mathrm{H}$-indosiyanin yeşili) ve $\mathrm{pH}$ duyarlı siyanin ( $\mathrm{pH}$-sensitive cyanine) boyaları bu tip problara örnek gösterilebilir [1].

İki fotonun lineer olarak absorbe edilmesi ve buna bağlı olarak floresan uyarımın meydana gelmesi esasına göre çalışan floresan problar (floroforlar) da mevcuttur. Bu düzenekte uygulanan tek fotonun enerjisi floresan uyarım için yeterli değildir. Özellikle enerjisi düşük dolayısıyla dalga boyu büyük fotonlarla uyarılan floroforlar bu kategoride ele alınmaktadırlar. Bu floroforlar büyük dalga boylu ışıkla çalıştıkları için özellikle derin doku çalışmalarında, tek foton floroforlara göre daha kullanışlıdırlar. Bu tip probların çalışma düzenlerinde, florofor bileşik, uyarıcı lazer ışığın fokus yaptığı bölgeden uyarılır (iki foton absorbe eder), bu durum hem çözünürlüğü arttırır ve hem de istenenen spesifik ışımanın net olarak elde edilmesini (arka-plan floresan ışımanın minimum düzeyde olmasını) sağlar. Squarinler (squarain dyes), BODIPY, pirimidiniyum (pyridinium), pirimidin (pyrimidine), ve trifenilamine (triphenylamine) türevleri iki foton absorbsiyonu esasına göre çalışan önemli florofor bileşiklerdir [26, 30, 31]. Yine voltaja duyarlı sentetik sRhoVR (sulfonated rhodamine voltage reporters) florofor bileşikleri bu kategorinin içinde değerlendirilebilirler. $\mathrm{Bu}$ floroforlar canlı dokuya uygulandıklarında hücrelerin plazma zarlarına lokalize olmakta (örneğin nöronların zarlarına) ve membranda depolarizasyon olması durumunda floresan ışımalarını arttırmaktadırlar. sRhoVR floroforları kültür hücrelerinde ve canlı hayvanlarda uzun süreli takibi gerektiren membran potansiyeli çalışmalarında kullanılabilirler [31].

Bazı florofor bileşikler dönebilen konjuge gruplar (rotatable conjugated moiety) içerirler. Dönebilen konjuge grubun serbest 
olarak döndüğü koşullarda (viskoz olmayan ortamlarda) ilgili floresan bileşik floresan ışıma yapamaz. Ancak dönebilen konjuge grubun kısıtlı olarak dönebildiği koşullarda (viskoz ortamlar) ilgili floresan bileşik ışıma yapar. Çiftli membran sistemi ile çevrili mitokondri yüksek viskozite göstermektedir. Bundan dolayı mitkondri ile ilgili görüntüleme çalışmalarında bu tip dönebilen konjuge grup içeren florofor bileşikler kullanılabilirler [26].

Organik floroforların yanı-sıra, son yıllarda in vivo görüntülemede kullanılmak üzere yakın kızılötesi floresan nano-partiküllerin (NIR nanoparticles) geliştirilmesine dönük çalışmalar yapılmaktadır. Yarı iletken nanokristal tabiatındaki quantum lekeleri (Quantum Dots, QDs) bu bağlamda önemlidirler. Dar ve ayarlanabilir emisyon bantları, yüksek molar tükenim katsayıları, yüksek quantum verimleri, geniş ve etkili stokes değişim değerleri ve fotosolmaya dirençli olma gibi özellikleri, quantum lekelerini in vivo görüntüleme açısından elverişli hale getirmektedir. Quantum lekeleri kadmiyum telurid (cadmium telluride) ve indiyum fosfamid (indium phosphamide) gibi bileşiklerin oluşturdukları materyallerden oluşmaktadırlar. $\mathrm{Bu}$ nano-partiküller 2 ile $10 \mathrm{~nm}$ eninde olup 200 ile 10.000 arasında değişen sayıda atom içerirler. Önceleri görünür ışık spektrumunda emisyon yapan quantum lekeleri biyolojik uygulamalarda kullanılırken, son zamanlarda yakın kızıötesi spektrumda emisyon yapan quantum lekelerinin geliştirilmesi üzerine çalışılmaktadır. Ebatlarına, kimyasal kompozisyonlarına ve yüzey kimyalarına bağlı olarak emisyonlarının görünürden kızılötesine kolayca değiştirilebilmesi quantum lekelerini biyolojik kullanım için çok elverişli hale getirmektedir. Quantum lekeleri hücre mikroskopisi uygulamalarının yanı-sıra canlı hayvan incelemelerinde de kullanılabilmektedirler. Kızıötesi quantum leke partikülleri hayvanlara subkutanöz veya intravenöz olarak enjekte edilmek suretiyle canlı hayvanda amaçlanan izleme yapılabilmektedir. $\mathrm{Bu}$ şekilde fare ve domuzlarda kan damarları ve lenfatik sistem izlemeleri yapılmıştır. Yine bir çalışmada bovin serum albümini ile kaplanmış $\mathrm{CdMnTe} / \mathrm{Hg}$ quantum leke partikülleri anjiyografik kontrast ajanı olarak kullanılmıştır [1]. Kadmiyum, teluryum ve selenyum gibi elementlerin akut ve kronik toksik etki göstermeleri, bu gibi elementlerden oluşmuş quantum leke partiküllerini in vivo izleme açısından sakıncalı hale getirmektedir [1].

Yakın kızılötesi boyalara bağlanmış nanopartiküller (NIR dye-labeled nanoparticles) in vivo görüntüleme amacıyla kullanılan farklı bir grup floresan bileşiği ifade etmektedir. Bu bileşiklerin çekirdek kısımlarını yakın kızılötesi floresan boya oluştururken, kabuk kısımlarını silika, kalsiyum fosfat veya organik nanopartiküller oluşturmaktadır. Nano-partiküller yakın kızılötesi boyalara kovalent veya kovalent olmayan bağlarla bağlanabilirler. Bazı özellikleri bu tip bileşikleri in vivo izleme açısından avantajlı hale getirmektedir. Kabuk yapısı yakın kızılötesi boyaları koruduğu için yüksek fotokararlılık (maruz kalınan ışığın kimyasal etkisine gösterilen direnç) gösterirler. Kabuk partikülleri hidrofilik materyallerden oluşturulmak suretiyle ilgili bileşiğin sudaki çözünürlüğü arttırılabilir. Bileşiği oluşturan boya ve nano-partikül molekül sayıları arasındaki oran değiştirilerek bileşiğin floresan özelliği arttırılabilir. Yine farklı biyo-molekülleri, kabuk yapısında bulunan fonksiyonel gruplara konjuge etmek suretiyle çoklu fonksiyon gösteren nano-partiküller oluşturulabilir. İndosiyanin yeşili boyasına bağlanmış silika nanopartiküller kullanılarak sıçanlarda in vivo izleme yapılmıştır [1].

Görünür spektrumda ışıma veren florofor bileşiklere kıyaslandıklarında yakın kızıl ötesi florofor bileşikler dokudan geçerken daha az foton kaybına uğrarlar, çözünürlük ve dokuya nüfuz edebilme özellikleri de daha yüksektir. İlave olarak görünür ışık spektrumundaki florofor bileşiklere kıyasla daha düşük düzeyde oto floresan (uyaran etkisi dışında kendiliğinden floresan ışıma yapma) özellik gösterirler [1, 26]. Her ne kadar 700-1000 nm arası dalga boylarında ışıma yapan florofor bileşikler yakın kızıl ötesi olarak kabul edilirlerse de, in vivo izleme için kullanılan florofor bileşiklerin çoğunluğu 700$900 \mathrm{~nm}$ arası dalga boylarında ışıma yaparlar $[1,26]$. Yakın kızıl ötesi florofor bileşiklerin bağlandığı organik moleküller (çeşitli peptidler, antikorlar ve siRNA), NIRF (near infra-Red fluoresecence optical imaging, yakın kızıötesi floresan görüntüleme) görüntüleme tekniği ile in vivo/sistemik olarak izlenebilmektedirler. Derin dokuda canlı izlemenin mümkün hale geldiği bu teknik ile yürütülen bir çalışmada; 
farelerde, deneysel olarak oluşturulan romatoid artrit olgusuna bağlı olarak gelişen kıkırdak hasarı izlenmiştir. İzleme düzeneği için tip Il kollajen proteinine bağlanan MMP750 ve Alexa Fluor 680 floresan boyaları farelere sistemik olarak verilmiş ve in vivo görüntüleme sistemi ile izleme yapılmıştır. İzleme düzeneği, romatoid artrit olgusuna bağlı olarak gelişen kıkırdak hasarını başarı ile göstermiştir [1, 32]. Yine yakın kızılötesi spektrumda ışıma yapan florofor bileşiklerin imaj destekli cerrahi operasyonlarda, alınacak dokuların görüntü eşliğinde daha hassas bir şekilde alınmasının yolunu açacağı öngörülmektedir. $\mathrm{Bu}$ şekilde cerrahi operasyonların etkinliğinin arttırılması hedeflenmektedir. Örneğin tümoral dokuların temizlenmesi operasyonlarında in vivo uygulanabilen bu florofor bileşiklerden faydalanılabilir [26]. İn vivo ve in selülo çalışmalarda kullanılan bazı florofor bileşikler ve özellikleri Tablo 1'de verilmiştir.

\section{Floresan ışımaya dayalı görüntüleme tekniklerinin avantajları-dezavantajları ve konuyla ilgili gelecek perspektifleri}

Floresan görüntülemeye dayalı teknikler; üzerinde çalışılan canlı organizmaya müdahaleyi gerektirmeyen, canlı dokuda olağan hücresel işlevleri bozmayan, yüksek çözünürlüklü görüntü elde edilmesini sağlayan, kesin sonuç veren, hassas ve ucuz tekniklerdir [26]. Klinik kullanım açısından floresan boyaların bazı özelliklerinin ileriye götürülmesi gerekmektedir. $\mathrm{Bu}$ bağlamda floresan boyaların hedef/arkaplan ışıma kontrastı (target:background ratio), hedefine özgün bağlanma, quantum verimi, absorbsiyon ve emisyon dalga boyları, suda çözünürlük, hücreye nüfuz edebilme ve floresan yaşam-süresi gibi özelliklerinin geliştirilmesi; bu boya maddelerini klinik kullanım açısından elverişli hale getirecektir. Yine ideal bir floresan boya maddesinin optik/fiziksel kararlılık göstermesi ve sitotoksik etki göstermemesi de gerekmektedir [26]. İn vivo ve canlı hücre çalışmalarında hücreye veya dokuya dışarıdan verilen floresan ajanın yapacağı ışımanın yanısıra, hücrede bulunan NADH, FAD, flavinler, keratin, kollajen, elastin, triptofan, tirozin, porfirin, lipofusinler, retinol ve melanin gibi bazı biyolojik maddelerin de oto-floresan ışıma yapabileceği göz önünde bulundurulmalıdır. Anılan biyolojik maddelerin oto-floresan ışıma oluşturmaları, sinyal karışımına ve istenen floresan sinyallerin net olarak alınmamasına yol açabilir. Endojen florofor bileşikler olarak kabul edilmekte olan bu oto-floresan bileşikler her hücreye özgün bir oto-floresan özellik kazandırmaktadırlar. Hücre gruplarının bu özgün oto-floresan özellikleri, onların doku veya organ ortamında tespitine ve bazı hastalık durumlarında geçirdikleri değişimlerin değerlendirilmesine yardımcı olabilmektedir. Halihazırda oto-floresan özellik, kolon-rektum ve akciğer kanserlerinin tanısında kullanılmaktadır $[17,33]$. Klasik floresan boyama ve floresan reporter genlerle izleme düzeneklerinin yanısıra floresan görüntülemenin bilgisayarlı tomografi, manyetik rezonans görüntüleme (MRI) teknikleri ile bir araya getirildiği multimodal düzenekler, daha ileri canlı izlemeler yapılmasını kolaylaştırmaktadırlar. İfade edilen çok kısımlı kompleks teknikler, özellikle fotonların yeterince penetre olamadıkları kalın dokularda ve üç boyutlu görüntü elde edilmesi çalışmalarında yararlı olmaktadırlar [15]. Sonuç olarak, bu çalışma kapsamında önemli görülen floresan görüntüleme teknikleri ve florofor bileşikler hakkında verilen bilgiler, bu konu hakkındaki çok geniş literatürden çok küçük bir kesit niteliğindedir. Bu konudaki teknolojilerin devamlı olarak ilerlemesi, daha fazla moleküler hedefin ve hastalığın in vivo olarak izlenmesini olanaklı kılacaktır. Özellikle floresan nanopartiküllerin gelecekte daha yaygın olarak in vivo izlemelerde kullanılacakları öngörülmektedir.

Çıkar ilişkisi: Yazarlar çıkar ilişkisi olmadığını beyan eder. 
Tablo 1. Yaygın olarak kullanılan florofor bileşikler ve özellikleri.

\begin{tabular}{|c|c|c|c|c|c|}
\hline Adı & $\begin{array}{l}\text { PADB } \\
(\mathrm{nm})\end{array}$ & $\begin{array}{l}\text { PEDB } \\
(\mathrm{nm})\end{array}$ & $\begin{array}{l}\text { Bağlandığı } \\
\text { önemli ligandlar }\end{array}$ & Önemli özellikleri & Kaynak \\
\hline Alexa Fluor 750 & 752 & 776 & $\begin{array}{l}\text { Triozin-ilişkili } \\
\text { proteinin(TRP2) } \\
\text { antikoruna bağlanırlar }\end{array}$ & $\begin{array}{l}\text { İn vivo çalışmaya } \\
\text { uygun }\end{array}$ & $\begin{array}{l}\text { salk.edu [9] } \\
\text { Fenton et al [10] }\end{array}$ \\
\hline $\begin{array}{l}\text { Indocyanine } \\
\text { green }\end{array}$ & $750-810$ & $>800$ & $\begin{array}{l}\text { Plazma albümin, } \\
\text { HDL, LDL }\end{array}$ & $\begin{array}{l}\text { İn vivo çalışmaya uygun } \\
\text { Toksik değil, } \\
\text { Yarı ömrü kısa }\end{array}$ & $\begin{array}{l}\text { Zhang et al [1] } \\
\text { Yoneya et al [11] } \\
\text { Alander et al [12] }\end{array}$ \\
\hline Squarainler & 630 & 650 & & $\begin{array}{l}\text { Yakın kızıl-ötesi } \\
\text { İn vivo izleme için uygun }\end{array}$ & $\begin{array}{l}\text { Zhang etal [1] } \\
\text { Freidus et al [26] }\end{array}$ \\
\hline Fluorescein & 495 & 519 & & $\begin{array}{l}\text { pH duyarlı, Tıbbi } \\
\text { tanı uygulamalarda } \\
\text { görüntüleme ajanı } \\
\text { kullanılmaktadır. }\end{array}$ & $\begin{array}{l}\text { salk.edu [9] } \\
\text { Robertson et al [33] } \\
\text { Alford et al [34] }\end{array}$ \\
\hline Bodipy FL & 503 & 512 & $\begin{array}{l}\text { İlaç, peptid, } \\
\text { karbonhidrat }\end{array}$ & $\begin{array}{l}\text { İn vivo çalışmaya } \\
\text { uygun }\end{array}$ & $\begin{array}{l}\text { salk.edu [9] } \\
\text { Giedt et al [35] } \\
\text { thermofisher.com [36] }\end{array}$ \\
\hline Bodipy R6G & 528 & 547 & $\begin{array}{l}\text { Phalloidin ve } \\
\text { Arg-Gly-Asp (RGD) } \\
\text { peptid'e } \\
\text { konjuge } \\
\text { olabilmektedir }\end{array}$ & $\begin{array}{l}\text { Radyoaktif versiyonu } \\
\text { in vivo çalışmada } \\
\text { kullanılmış }\end{array}$ & $\begin{array}{l}\text { Alford et al [34] } \\
\text { emu.uct.ac.za [37] } \\
\text { Liu et al [38] }\end{array}$ \\
\hline Су 5.5 & 675 & 694 & & İn vivo çalışmaya uygun & $\frac{\text { salk.edu [9] }}{\text { Lee at al [39] }}$ \\
\hline Niad-4 & $475-480$ & $625-650$ & B-amiloid & İn vivo çalışmaya uygun & $\begin{array}{l}\text { Rao et al [15] } \\
\text { Bae et al [40] }\end{array}$ \\
\hline Tokyo green & 491 & 510 & & $\begin{array}{l}\text { Hidrofobik, } \\
\text { Toksik değil }\end{array}$ & $\begin{array}{l}\text { Alford et al [34] } \\
\text { Mottram et al [41] }\end{array}$ \\
\hline Oregon green & $490-496$ & $514-524$ & $\begin{array}{l}\text { Türevi kalsiyum } \\
\text { indikatörü }\end{array}$ & $\begin{array}{l}\text { Türevi, hücre içi kalsiyum } \\
\text { düzeylerinin } \\
\text { İn vivo izlenmesinde } \\
\text { kullanılmıştır }\end{array}$ & $\begin{array}{l}\text { Alford et al [34] } \\
\text { Mottram et al [41] } \\
\text { Cirillo etal [42] }\end{array}$ \\
\hline Rhodamine 110 & 505 & 527 & $\begin{array}{l}\text { Enzim aktivite } \\
\text { çalışmalarında } \\
\text { kullanılmaktadır }\end{array}$ & Canlı hücrelerde çalışılmış & $\begin{array}{l}\text { Alford et al [34] } \\
\text { Beija et al [43] }\end{array}$ \\
\hline $\begin{array}{l}\text { Rhodamine X } \\
\text { (6-carboxy-X- } \\
\text { rhodamine,6-ROX) }\end{array}$ & 575 & 602 & $\begin{array}{l}\text { GmSA ile konjuge } \\
\text { formu D-galaktoz } \\
\text { reseptörü,Hücre-içi } \\
\text { civa sensörü }\end{array}$ & İn vivo çalışmaya uygun & $\begin{array}{l}\text { Alford et al [34] } \\
\text { Zhang et al [44] } \\
\text { Hama et al [45] }\end{array}$ \\
\hline $\begin{array}{l}\text { 6-TAMRA } \\
\text { (6-carboxytetra } \\
\text { methylrhodamine) }\end{array}$ & 555 & 580 & $\begin{array}{l}\text { G5 dendrimer-leri ve } \\
\text { folik asit ile konjuge } \\
\text { halde folik asit } \\
\text { reseptörüne bağlanır }\end{array}$ & İn vivo çalışmaya uygun & $\begin{array}{l}\text { Alford et al [34] } \\
\text { Thomas et al [46] }\end{array}$ \\
\hline Rhodol türevleri & $490-550$ & $520-580$ & & $\begin{array}{l}\text { Foto-kararlıdırlar, } \\
\text { İyon izlemeleri için } \\
\text { uygundurlar }\end{array}$ & $\begin{array}{l}\text { Whitaker et al [47] } \\
\text { Poronik et al [48] } \\
\text { Li et al [49] }\end{array}$ \\
\hline Texas red & $588-589$ & $601-615$ & $\begin{array}{l}\text { Dana serum } \\
\text { albüminine konjuge } \\
\text { olabilmektedir }\end{array}$ & İn vivo çalışmaya uygun & $\begin{array}{l}\text { salk.edu [9] } \\
\text { Alford et al [34] } \\
\text { Miller et al [50] }\end{array}$ \\
\hline
\end{tabular}

PADB: pik absorbsiyon dalga boyu, PEDB: pik emisyon dalga boyu, HDL:yüksek dansiteli lipoprotein, LDL:düşük dansiteli lipoprotein, GmSA: galaktozamine konjuge serum albümini. 


\section{Kaynaklar}

1. Zhang X, Bloch S, Akers W, Achilefu S. Nearinfrared molecular probes for in vivo imaging. Curr Protoc Cytom 2012;chapter12:unit12.27. https://doi. org/10.1002/0471142956.cy1227s60

2. Suhling K, Hirvonena LM, Levitt JA, et al. Fluorescence lifetime imaging (FLIM): basic concepts and some recent developments. Med Photon 2015;27:3-40. http://dx.doi.org/10.1016/j.medpho.2014.12.001

3. Sauer L, Andersen KM, Dysli C, Zinkernagel MS, Bernstein PS, Hammer M. Review of clinical approaches in fluorescence lifetime imaging ophthalmoscopy. J Biomed Opt 2018;23:091415. https://doi.org/10.1117/1. JBO.23.9.091415

4. Li Q, Tang $\mathrm{Y}, \mathrm{Hu} \mathrm{W}, \mathrm{Li}$ Z. Fluorescence of nonaromatic organic systems and room temperature phosphorescence of organic luminogens: the intrinsic principle and recent progress. Small 2018;14:e1801560. https://doi.org/10.1002/smll.201801560

5. Basic principles of fluorescence spectroscopy. Available at: https://application.wiley-vch.de/books/ sample/3527316698_c01.pdf. accessed data 18 Mart 2019. (Accessed March 18, 2019.)

6. Süel G. Use of fluorescence microscopy to analyze genetic circuit dynamics. Methods Enzymol 2011;497:275-293. https://doi.org/10.1016/B978-0-12385075-1.00013-5

7. Haustein E, Schwille P. Trends in fluorescence imaging and related techniques to unravel biological information. HFSP J 2007;1:169-180. https://doi. org/10.2976/1.2778852

8. Donya M, Radford M, ElGuindy A, Firmin D, Yacoub MH. Radiation in medicine: origins, risks and aspirations. Glob Cardiol Sci Pract 2014;2014:437448. http://dx.doi.org/10.5339/gcsp.2014.57

9. Table of fluorochromes. Available at: https://www.salk. edu/pdf/fluorochrome-table.html. accessed data 3 Mayıs 2019. (Accessed May 3, 2019.)

10. Fenton KE, Martirosyan NL, Abdelwahab MG, Coons SW, Preul MC, Scheck AC. In vivo visualization of GL261-luc2 mouse glioma cells by use of Alexa Fluor-labeled TRP-2 antibodies. Neurosurg Focus 2014;36:E12. http://thejns.org/doi/ abs/10.3171/2013.12.FOCUS13488

11. Yoneya S, Saito T, Komatsu Y, Koyama I, Takahashi $\mathrm{K}$, Duvoll-Young J. Binding properties of indocyanine green in human blood. Invest Ophthalmol Vis Sci 1998;39:1286-1290

12. Alander JT, Kaartinen I, Laakso A, et al. A review of indocyanine green fluorescent imaging in surgery. Int J Biomed Imaging 2012;2012:940585. http://dx.doi. org/10.1155/2012/940585
13. Hassan M, Riley J, Chernomordik V, et al. Fluorescence lifetime imaging system for in vivo studies. Mol Imaging 2007;6:229-236. https://doi. org/10.2310/7290.2007.00019

14. Miao Y, Gu C, Zhu Y, Yu B, Shen Y, Cong H. Recent progress in fluorescence imaging of the near-infrared II window. Chembiochem 2018;19:2522-2541. https:// doi.org/10.1002/cbic.201800466

15. Rao J, Dragulescu-Andrasi A, Yao H. Fluorescence imaging in vivo: Recent advances. Curr Opin Biotechnol 2007;18:17-25. https://doi.org/10.1016/j. copbio.2007.01.003

16. Dancik Y, Favre A, Loy CJ, Zvyagin AV, Roberts MS. Use of multiphoton tomography and fluorescence lifetime imaging to investigate skin pigmentation in vivo. J Biomed Opt 2013;18:26022. https://doi. org/10.1117/1.JBO.18.2.026022

17. Chorvat D Jr, Chorvatova A. Multi-wavelength fluorescence lifetime spectroscopy: a new approach to the study of endogenous fluorescence in living cells and tissues. Laser Phys Lett 2009;6:175-193. https:// doi.org/10.1002/lapl.200810132

18. Won Y, Park B, Kim I, Lee S. Fluorescence lifetime measurement with confocal endomicroscopy for direct analysis of tissue biochemistry in vivo. Heliyon 2016:2;e00139. https://doi.org/10.1016/j.heliyon.2016. e00139

19. De Los Santos C, Chang CW, Mycek MA, Cardullo RA. FRAP, FLIM, and FRET: detection and analysis of cellular dynamics on a molecular scale using fluorescence microscopy. Mol Reprod Dev 2015;82:587-604. https://doi.org/10.1002/mrd.22501

20. Becker W. Fluorescence lifetime imaging--techniques and applications. J Microsc 2012;247:119-136. https:// doi.org/10.1111/j.1365-2818.2012.03618.x

21. Fruhwirth GO, Matthews DR, Brock $A$, et al. Deeptissue multi-photon fluorescence lifetime microscopy for intravital imaging of protein-protein interactions. Proc of SPIE 2009;7183:71830L. https://doi. org/10.1117/12.817129

22. Fruhwirth GO, Fernandes LP, Weitsman G, et al. How Förster resonance energy transfer imaging improves the understanding of protein interaction networks in cancer biology. Chemphyschem 2011;12:442-461. https://doi.org/10.1002/cphc.201000866

23. Kaminski CF, Rees EJ, Schierle GS. A quantitative protocol for intensity-based live cell FRET imaging. Methods Mol Biol 2014;1076:445-454. https://doi. org/10.1007/978-1-62703-649-8_19

24. Ma T, Hou Y, Zeng J, et al. Dual-ratiometric targettriggered fluorescent probe for simultaneous quantitative visualization of tumor microenvironment protease activity and $\mathrm{pH}$ in vivo. J Am Chem Soc 2018;140:211-218. https://doi.org/10.1021/ jacs. 7 b08900 
25. Stockert JC, Blázquez-Castro A. Fluorescence microscopy in life sciences. In: Chapter 3 dyes and fluorochromes. Bentham e-books, Bentham Science Publishers 2017;61-95. Available at:https://books. google.com.tr/books?id=4stFDwAAQBAJ\&g=PA61\&d $\mathrm{q} \# \mathrm{v}=$ onepage $\& \mathrm{q} \& \mathrm{f}=$ false. accessed data $8 \mathrm{Temmuz}$ 2019. (Accessed July 8, 2019.)

26. Freidus LG, Pradeep P, Kumar P, Choonara YE, Pillay V. Alternative fluorophores designed for advanced molecular imaging. Drug Discov Today 2018;23:115133. https://doi.org/10.1016/j.drudis.2017.09.008

27. Fu H, Cui M, Zhao L, et al. Highly sensitive near-infrared fluorophores for in vivo detection of amyloid- $\beta$ plaques in alzheimer's disease. J Med Chem 2015;58:69726983. https://doi.org/10.1021/acs.jmedchem.5b00861

28. Park GK, Lee JH, Levitz A, et al. Lysosome-targeted bioprobes for sequential cell tracking from macroscopic to microscopic scales. Adv Mater 2019;31:e1806216. https://doi.org/10.1002/adma.201806216

29. Pedro Carvalho PHPR, Correa JR, Guido BC, et al. Designed benzothiadiazole fluorophores for selective mitochondrial imaging and dynamics. Chem Eur J 2014;20:15360-15374. https://doi.org/10.1002/ chem. 201404039

30. Zhang $\mathrm{Q}$, Tian $\mathrm{X}$, Zhou $\mathrm{H}, \mathrm{Wu} \mathrm{J}$, Tian $\mathrm{Y}$. Lighting the way to see inside two-photon absorption materials: structure-property relationship and biological imaging. Materials (Basel) 2017;10;E223. https://doi. org/10.3390/ma10030223

31. Kulkarni RU, Vandenberghe M, Thunemann M, et al. In vivo two-photon voltage imaging with sulfonated rhodamine dyes. ACS Cent Sci 2018;4:1371-1378. https://doi.org/10.1021/acscentsci.8b00422

32. Cho H, Bhatti FU, Lee S, Brand DD, Yi AK, Hasty KA. In vivo dual fluorescence imaging to detect joint destruction. Artif Organs 2016;40:1009-1013. https:// doi.org/10.1111/aor.12685

33. Robertson TA, Bunel F, Roberts MS. Fluorescein derivatives in intravital fluorescence imaging. Cells 2013;2:591-606. https://doi.org/10.3390/cells2030591

34. Alford R, Simpson HM, Duberman J, et al. Toxicity of organic fluorophores used in molecular imaging: literature review. Mol Imaging 2009;8:341-354. https:// doi.org/10.2310/7290.2009.00031

35. Giedt RJ, Koch PD, Weissleder R. Single cell analysis of drug distribution by intravital imaging. PLoS One 2013;8:e60988. https://doi.org/10.1371/journal. pone. 0060988

36. BODIPY dye series-section 1.4. Available at:https:// www.thermofisher.com/tr/en/home/references/ molecular-probes-the-handbook/fluorophores-andtheir-amine-reactive-derivatives/bodipy-dye series. html. accessed data 21 Mayıs 2019. (Accessed May 21, 2019.)
37. Probes for actin. Available at:http://www.emu.uct.ac.za/ sites/default/files/image_tool/images/430/lecture-4intracellular-localisation/actin.pdf accessed data 21 Mayıs 2019. (Accessed May 21, 2019.)

38. Liu S, Lin TP, Li D, et al. Lewis acid-assisted isotopic ${ }^{18} \mathrm{~F}-{ }^{19} \mathrm{~F}$ exchange in BODIPY dyes: facile generation of positron emission tomography/fluorescence dual modality agents for tumor imaging. Theranostics 2013;3:181-189. https://doi.org/10.7150/thno.5984

39. Lee $\mathrm{KH}$, Nam $\mathrm{H}$, Won JS, et al. In vivo spinal distribution of Cy5.5 fluorescent dye after injection via the lateral ventricle and cisterna magna in rat model. J Korean Neurosurg Soc 2018;61:434-440. https://doi. org/10.3340/jkns.2017.0252

40. Bae S, Lima E, Hwang D, Huh H, Kim SK. Torsiondependent fluorescence switching of amyloid-binding dye NIAD-4. Chemical Physics Letters 2015;633:109113. https://doi.org/10.1016/j.cplett.2015.05.010

41. Mottram L, Boonyarattanakalin S, Kovel RE, Peterson BR. The Pennsylvania Green Fluorophore: a hybrid of Oregon Green and Tokyo Green for the construction of hydrophobic and $\mathrm{pH}$-insensitive molecular probes. Org Lett 2006;8:581-584. https://doi.org/10.1021/ ol052655g

42. Cirillo G, Luca DD, Papa M. Calcium imaging of living astrocytes in the mouse spinal cord following sensory stimulation. Neural Plast 2012;2012:425818. http:// dx.doi.org/10.1155/2012/425818

43. Beija M, Afonso CAM, Martinho JMG. Synthesis and applications of Rhodamine derivatives as fluorescent probes. Chem Soc Rev 2009;38:2410-2433. https:// doi.org/10.1039/b901612k

44. Zhang Y, Guo S, Jiang Z, Mao G, Ji X, He Z. Rox-DNA functionalized silicon nanodots for ratiometric detection of mercury ions in live cells. Anal Chem 2018;90:97969804. https://doi.org/10.1021/acs.analchem.8b01574

45. Hama Y, Urano Y, Koyama Y, Gunn AJ, Choyke PL, Kobayashi $H$. A self-quenched galactosamine-serum albumin-rhodamineX conjugate: a "smart" fluorescent molecular imaging probe synthesized with clinically applicable material for detecting peritoneal ovarian cancer metastases. Clin Cancer Res 2007;13:63356343. https://doi.org/10.1158/1078-0432.CCR-07-1004

46. Thomas TP, Myaing MT, Ye JY, et al. Detection and analysis of tumor fluorescence using a two-photon optical fiber probe. Biophys J 2004;86:3959-3965. https://doi.org/10.1529/biophysj.103.034462

47. Whitaker JE, Haugland RP, Ryan D, Hewitt PC, Haugland RP, Prendergast FG. Fluorescent rhodol derivatives: Versatile, photostable labels and tracers. Anal Biochem 1992;207:267-279. https://doi. org/10.1016/0003-2697(92)90011-U

48. Poronik YM, Clermont G, Blanchard-Desce M, Gryko DT. Nonlinear optical chemosensor for sodium ion based on rhodol chromophore. J Org Chem 2013;78:1172111732. https://doi.org/10.1021/jo401653t 
49. Li L, Wang $\mathrm{S}$, Lan $\mathrm{H}$, et al. Rhodol derivatives as selective fluorescent probes for the detection of $\mathrm{Hg}^{\prime \prime}$ ions and the bioimaging of hypochlorous acid. ChemistryOpen 2018;7:136-143. https://doi. org/10.1002/open.201700154

50. Miller DR, Hassan AM, Jarrett JW, et al. In vivo multiphoton imaging of a diverse array of fluorophores to investigate deep neurovascular structure. Biomed Opt Express 2017;8:3470-3481. https://doi. org/10.1364/BOE.8.003470

Teşekkür: Sağladığı geniş elektronik veri tabanları olanağından dolayı Çukurova Üniversitesi Kütüphanesi'ne teşekkür ederim. 